\title{
PENDAMPINGAN PEMANFAATAN PROGRAM ACCURATE PADA STAF AKUNTANSI BADAN PENGELOLA USAHA (BPU) UNIVERSITAS MATARAM
}

\section{Assistance for the Utilization of the "Accurate Program" for the Accounting Staff of the Business Management Agency (BPU), Mataram University}

\author{
Indria Puspitasari Lenap*, Nina Karina Karim, Elin Erlina Sasanti \\ Jurusan Akuntansi Fakultas Ekonomi dan Bisnis Universitas Mataram \\ Jalan Majapahit Nomor 62 Kota Mataram Provinsi NTB \\ *Alamat korespondensi : indrialenap@unram.ac.id
}

(Tanggal Submission: 16 July 2020, Tanggal Accepted: 29 Agustus 2020)

\begin{abstract}
ABSTRAK
Sebagai pusat bisnis yang mengelola aset Universitas Mataram, terdapat cukup banyak jenis transaksi dari berbagai bidang usaha yang harus di maintain oleh BPU, yang dalam hal ini yaitu StafAkuntansi. Pencatatan menggunakan Excel hanya menghasilkan informasi pendapatan dan belanja, bukan laporan komprehensif.Pemanfaatan program Accurate sangat tepat dalam menyediakan laporan keuanganpada BPU serta memudahkan Staf Akuntansi dalam menyiapkan informasi keuangan BPU. Sesi ceramah dan tutorial dimulai dari penjelasan dasar dan sistematis tentang program Accurate yang disertai dengan tutorial yang dilengkapi dengan modul praktik, instalasi dan setting awal program. Selanjutnya, sesi praktik dilakukan penginputan transaksi yang secara teknis meliputi transaksi pendapatan dan belanja yang masing-masing dipisahkan berdasarkan pos (sub akun dari pendapatan maupun belanja).Pemisahan pendapatan dilakukan karena masing-masing unit memiliki PIC (Person In Charge) atau penanggung jawab (manajer) yang berbeda, sehingga dapat menjadi kontrol kinerja dan evaluasi kinerja bagi para manajer unit Usaha BPU. Sementara, pemisahan belanja dipisahkan berdasarkan jenis belanja karena masing-masing kegiatan terbagi dalam pos yang berbeda, sehingga akan mempermudah kontrol dan pengecekan realisasi belanja dengan anggaran belanja tahun yang bersangkutan.Sesi terakhir dilanjutkan dengan diskusi. Sesi terakhir yaitu diskusi yang diisi dengan tanya jawab peserta dan sharing terkait kendala dalam hal teknis dan administratif dalam pencatatan buku dan pengoperasian program Accurate. Dengan adanya kegiatan pengabdian ini, Staf Akuntansi BPU sudah mampu mengoperasikan sendiri program Accurate yang sudah kami ajarkan dan saat ini aktivitas pencatatan transaksi BPU sudah menerapkan sistem pelaporan berbasis teknologi informasi.
\end{abstract}

Kata Kunci : pendampingan, program Accurate, BPU Unram 


\section{PENDAHULUAN}

Perkembangan di dalam dunia Akuntansi tidak terlepas dari perkembangan teknologi dalam informasi dan komunikasi.Salah satu yang berkembang dan umum diimplementasikan dalam dunia bisnis adalah aplikasi sistem komputer Akuntansi atau sering disebut dengan software Akuntansi. Keamanan data bisnis melalui pembukuan secara manual memiliki banyak kelemahan. Sehingga saat ini cara manual telah banyak ditinggalkan (Utami, 2019).

Siklus pengolahan transaksi merupakan prinsip dasar bagaimana kejadian ekonomi dapat diklasifikasikan sebagai proses bagaimana entitas laporan usaha mengkontribusikan dokumen transaksi sebagai masukan untuk menjadi laporan keuangan. Pembukuan dengan program aplikasi Akuntansi diawali dengan pencatatan setiap transaksi ke dalam jurnal, kemudian secara otomatis perkiraan akan mengupdate setiap inputan yang maksud untuk kemudian dibuat bagaimana laporan yang akan ditampilkan (Asmuni, 2005).

Salah satu program Akuntansi yang cukup banyak digunakan karena dapat menghasilkan laporan keuangan yang mudah dan cepat adalah program Accurate. Proses atau tahapan dalam penggunaan program Accuratedimulai dari instalasi pada perangkat komputer, pembuatan profil perusahaan, pengisian akun, proses transaksi pembelian dan penjualan, hingga pembuatan dan pencetakan laporan keuangan serta evaluasi program (Hapsari dkk, 2017).

Pemanfaatan program Accuratetidak hanya digunakan pada entitas bisnis, namun juga pada entitas pemerintahan dikarenakan fleksibilitas dalam pencatatan akun-akun pada aplikasi. Badan Pengelola Usaha (BPU) Universitas Mataram adalah salah satu unit kerja pada Universitas Mataram yang khusus mengelola aset milik Unram untuk dimanfaatkan sehingga dapat menghasilkan pendapatan bagi Unram selain dari UKT mahasiswa. Terdapat dua bidang usaha di
BPU Unram yaitu produksi dan jasa yang meliputi bidang akademik non-akademik yang setiap harinya secara rutin menyetorkan pendapatan ke Staf BPU.

Tercatat sebanyak Rp. 352.205.236,- total pendapatan yang dihasilkan oleh BPU pada tahun 2019 dan diprediksi pada tahun 2020 akan menghasilkan pendapatan di atas 1 Miliar Rupiah. Selain itu, terdapat pula transaksi belanja yang dilakukan untuk kebutuhan sehari-hari BPU, dengan jatah anggaran sebesar Rp. 200.000.000,- dalam satu tahun. Selama ini, pencatatan transaksi keuangan dicatat menggunakan MicrosoftExcel. Sehingga, tidak dapat secara langsung menghasilkan output laporan pendapatan dan belanja. Diharapkan dengan pemanfaatan program Accuratepada BPU dapat memudahkan StafAkuntansi BPU dalam menyiapkan laporan keuangan (pendapatan dan belanja) baik secara periodik maupun tahunan.

Sebagai pusat bisnis yang mengelola aset Universitas Mataram, terdapat cukup banyak jenis transaksi dari berbagai bidang usaha yang harus di maintain dan dicatat secara menggunakan program Excel oleh Staf Akuntansi BPU. Namun, tentu saja pencatatan menggunakan Excel hanya menghasilkan informasi pendapatan dan belanja, bukan laporan komprehensif. Tercatat ada dua bidang usaha induk dalam struktur BPU yaitu produksi dan jasa, yang keduanya memiliki unit-unit usaha yang setiap harinya menghasilkan pendapatan bagi Universitas Mataram. Selain, itu adanya permintaan belanja yang tentunya juga terjadi secara rutin.

Pemanfaatan program Accurate dalam bidang Akuntansi sangat tepat dalam menyediakan laporan keuanganpada BPU serta memudahkan Staf Akuntansi dalam menyiapkan informasi keuangan BPU berupa laporan pendapatan belanja yang dibutuhkan dalam membuat kebijakan penting. Kedepannya, diharapkan implementasi program ini dapat terus diterapkan pada BPU Universitas Mataram. 


\section{METODE KEGIATAN}

Metode partisipatif berbasis teknologi informasi dengan pendekatan andragogi merupakan metode dan pendekatan yang dipilih guna mencapai kompetensi sosialisasi dan pelatihan. Pendekatan ini merupakan pendekatan pembelajaran untuk orang dewasa yang dalam hal ini adalah Staf Akuntansi Badan Pengelola Usaha Universitas Mataram, yang belokasi di Jalan Majapahit No. 62 Mataram. Komponen pelatihanterdiri dari dua yaitu penyampaian materi secara searah (ceramah dan tutorial) sebesar $50 \%$ dan sesi praktik sebesar 50\%. Adapun tahapan dan materi pelaksanaan kegiatan pengabdian ini dilakukan dengan metode ceramah, tutorial, praktik dan diskusi dengan langkah-langkah berikut ini :

1. Metode ceramah

Peserta diberikan pengetahuan dan pemahaman melalui presentasi oleh pemateri serta motivasi agar memiliki bekal dalam mengoperasikan program Accuratedan memudahkan Staf Akuntansi BPU dalam menyiapkan informasi keuangan. Metode ini dilakukan selama $1 / 2$ jam.

2. Metode tutorial

Peserta diberikan modul yang berisi langkah-langkah settingan awal perogram, cara membuat bagan akun dan menginput transaksi serta mengarsipkan output laporan keuangan (pendapatan dan belanja) yang dihasilkan oleh program Accurate. Peserta diberikan pengarahan dan simulasi menggunakan program Accurate. Metode ini dilakukan selama 1 jam.
3. Sesi praktik

Peserta mempraktikkan program Accurate untuk menginput data transaksi BPU sampai menghasilkan laporan pendapatan dan belanja. Metode ini dilakukan selama 2 jam.

4. Metode diskusi

Peserta diberikan kesempatan untuk mendiskusikan masalah yang dihadapi berkaitan dengan kesulitan dalam aspek pengoperasian program Accurate. Metode ini dilakukan selama $1 / 2 \mathrm{jam}$.

\section{HASIL DAN PEMBAHASAN}

Kegiatan pengabdian ini ditujukan untuk mengatasi permasalahan dalam penyajian laporan pendapatan dan belanja baik secara periodik maupun tahunan yang ada di Badan Pengelola Usaha (BPU) Universitas Mataram. Kegiatan pengabdian ini berlangsung dalam waktu satu hari yang diawali dengan penjelasan dasar dan sistematis tentang program Accurateyang disertai dengan tutorial yang dilengkapi dengan modul praktik, instalasi dan setting awal program. Setting awal mencakup aktivitas seperti set up data perusahaan, pengaturan daftar akun (bagan akun disesuaikan dengan jenis transaksi yang ada di BPU). Berhubung StafAkuntansi di BPU memiliki background Sarjana Akuntansi, hal ini mempermudah kami dalam proses pengenalan aplikasi, pelatihan dan praktik, karena dalam kurikulum S1 Akuntansi terdapat mata kuliah Akuntansi Berbasis Komputer yang salah satunya memuat materi praktikum program AkuntansiAccurate. 




Gambar 1. Sesi tutorial dan praktik

Setelah itu, dilanjutkan dengan kegiatan praktik. Seperti yang telah dijelaskan sebelumnya bahwa pencatatan yang selama ini dilakukan oleh StafAkuntansi BPU hanya sebatas pencatatan manual yang diinput ke microfost Excel, di mana data Excelini yang dijadikan sebagai data laporan keuangan (pendapatan dan belanja). Kegiatan ini merupakan inti dari kegiatan pengabdian, karena sekaligus akan memproses transaksi keuangan baik pendapatan maupun belanja yang dilakukan oleh BPU ke dalam program AkuntansiAccurate. Penginputan transaksi yang secara teknis meliputi transaksi pendapatan dan belanja yang masingmasing dipisahkan berdasarkan pos (sub akun dari pendapatan maupun belanja). Pendapatan yang diproses dibagi ke dalam sub akun pendapatan dari sewa kantin, gedung, rusunawa, penjualan dan jasa lainnya. Sementara belanja yang diproses seperti belanja ATK, belanja rumah tangga, dan pengeluaran lainnya. Pemisahan pendapatan dilakukan karena masing-masing unit memiliki PIC (Person In Charge) atau penanggung jawab (manajer) yang berbeda, sehingga dapat menjadi kontrol kinerja dan evaluasi kinerja bagi para manajer unit Usaha BPU. Sementara, pemisahan belanja dipisahkan berdasarkan jenis belanja karena masing-masing kegiatan terbagi dalam pos yang berbeda, sehingga akan mempermudah kontrol dan pengecekan realisasi belanja dengan anggaran belanja tahun yang bersangkutan.

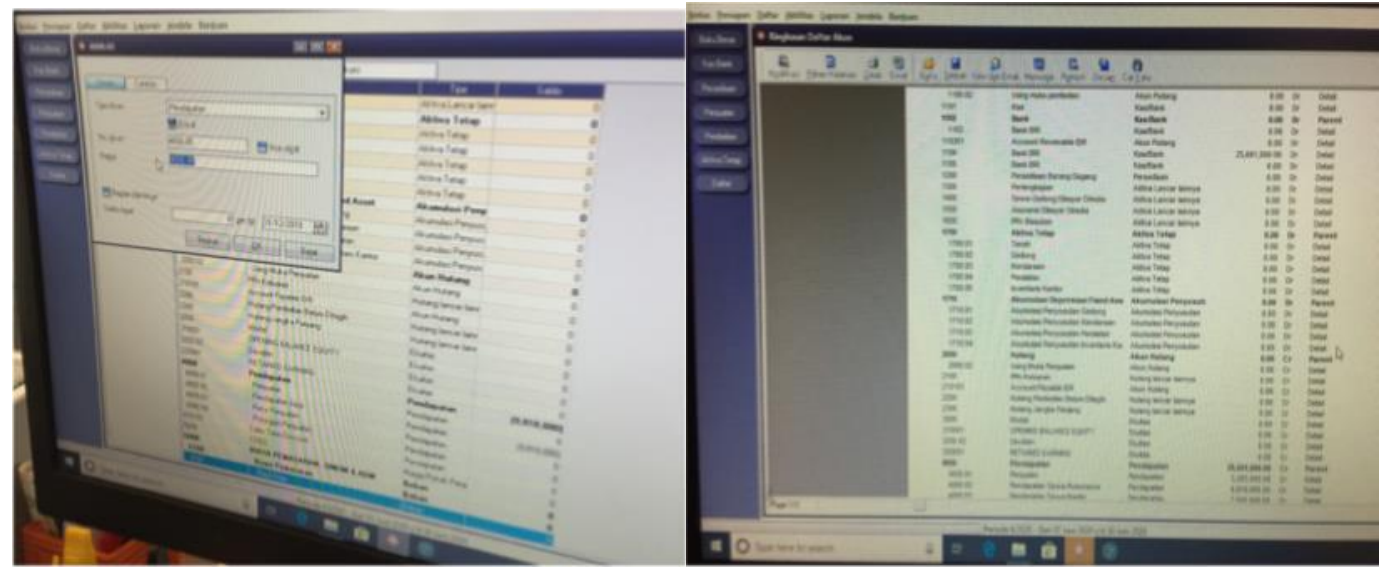

Gambar 2. Tampilan output transaksi 
Sesi terakhir dilanjutkan dengan diskusi. Pada sesi ini, peserta diberikan kesempatan untuk bertanya tentang segala hal terkait aspek teknis pengoperasian program Accurate. Sesi diskusi diisi dengan tanya jawab peserta dan sharing terkait kendala dalam entry data serta berbagai permasalahan dalam menentukan remark (keterangan transaksi) yang tepat pada program Accurate. Kami juga memberi saran dan masukan terkait hal administratif seperti cara penulisan remark pada bukti transfer, cara me-maintain pencatatan dan pengecekan berkala antara bukti transfer dengan buku serta pengarsipan (filling management) yang baik. Penulisan remark yang tepat saat melakukan transfer ke rekening Rektor akan memudahkan pengecekan antara rekening koran dengan bukti transfer (catatan) yang ada di BPU. Selain itu, berguna juga saat meng-entry transaksi ke program Accurate.

Kegiatan pengabdian ini tentunya sangat bermanfaat, mengingat pencatatan transaksi yang rapih serta laporan keuangan yang lengkap tentu akan mencapai tujuan relevansinya manakala pengguna khususnya pihak internal suatu entitas membutuhkan informasi keuangan. Namun, ketersediaan laporan yang komprehensif membutuhkan adanya sebuah sistem informasi yang mampu mengolah data keuangan dengan cepat. Pencatatan transaksi secara manual yang selama ini dilakukan oleh Staf Akuntansi BPU memiliki kelemahan dari segi efektivitas dan efisiensi waktu. Sehingga dengan adanya kegiatan pengabdian ini, Staf Akuntansi BPU sudah mampu mengoperasikan sendiri program Accurate yang sudah kami ajarkan dan saat ini aktivitas pencatatan transaksi BPU sudah menerapkan sistem pelaporan berbasis teknologi informasi.

\section{KESIMPULAN DAN SARAN}

Kegiatan pengabdian berlangsung dalam satu hari yang diawali dengan ceramah dan tutorial yaitu penjelasan dasar dan sistematis tentang program Accurate yang disertai dengan tutorial yang dilengkapi dengan modul praktik, instalasi dan setting awal program. Lalu, praktik dilakukan dengan penginputan transaksi yang secara teknis meliputi transaksi pendapatan dan belanja yang masing-masing dipisahkan berdasarkan pos (sub akun dari pendapatan maupun belanja). Sesi terakhir yaitu diskusi, diisi dengan tanya jawab peserta dan sharing terkait kendala dalam entry data serta berbagai permasalahan dalam pengoperasian (teknis) dan hal administratif terkait program Accurate. Dengan adanya kegiatan pengabdian ini, Staf Akuntansi BPU sudah mampu mengoperasikan sendiri program Accurate yang sudah kami ajarkan dan saat ini aktivitas pencatatan transaksi BPU sudah menerapkan sistem pelaporan berbasis teknologi informasi. Sebagai saran untuk pengabdian berikutnya yang serupa adalah sangat penting dalam melakukan survei awal secara detail terkait sasaran (khalayak) yang akan menjadi objek pengabdian karena akan mempengaruhi efektivitas dalam pelaksanaan kegiatan. Sebagai contoh, jika akan memberikan pelatihan tentang teknologi informasi yang berbasis sistem atau aplikasi tertentu, harus memastikan bahwa peserta memiliki pengetahuan dasar atas sistem atau aplikasi tersebut karena akan memudahkan pemahaman peserta maupun Tim pengabdian ketika praktik (pengoperasian) saat pelaksanaan kegiatan.

\section{UCAPAN TERIMA KASIH}

Kami mengucapkan terima kasih kepada Rektor dan Dekan Fakultas Ekonomi Universitas Mataram atas dukungan dana yang diberikan kepada Tim pengabdian sehingga dapat melaksanakan kegiatan dengan lancar dan sesuai dengan yang diharapkan. 


\section{DAFTAR PUSTAKA}

Asmuni. I. 2005. Tinjauan atas Proses Pembukuan dengan Program Aplikasi terhadap Informasi Akuntansi. Seminar Nasional Teknologi Informasi 2005.

Hapsari, D.I., Kresnadipayana. D. dan Pamungkas, G.S. 2017. Pelatihan Peningkatan Manajemen Keuangan Berbasis Software pada
UMKM (Studi Kasus pada UMKM Sidomukti dan Sri Rejeki di Kecamatan Jenawi. Abdimas Unwahas, Vol. 2 No. 2, Oktober 2017 ISSN 2541-1608 e-ISSN 25797123.

Utami, N.W. 2019. Pembukuan Manual vs Software Akuntansi, Mana yang Lebih Efektif ?. https://www.jurnal.id/pembukuanmanual-vs-software-Akuntansi/. 